\title{
ROLE OF THE FUNGAL CELL WALL IN THE GRANULOMATOUS RESPONSE OF MICE TO THE AGENTS OF CHROMOMYCOSIS
}

\author{
C. L. Silva and Raquel A. Fazioli \\ Department of Parasitology, Microbiology and Immunology, School of Medicine of \\ Ribeirão Preto, University of São Paulo, 14.100-Ribeirão Preto-SP, Brazil

\begin{abstract}
SUMmaRY. Mice were given, intraperitoneally, inocula of a cell-wall preparation and fractions thereof from Fonsecaea pedrosoi, F. compactum, Cladosporium carrioni and Phialophora verrucosum. Large doses of cell-wall preparation, with or without trypsin treatment, produced a pronounced loss of body weight, a granulomatous reaction and, sometimes, death. After extraction of the cell wall preparation with $1 \mathrm{~N}$ $\mathrm{NaOH}$, three fractions were obtained: an alkali-insoluble fraction 1; an alkali-soluble acid-insoluble fraction 2; and an alkali- and acid-soluble fraction 3. Intravenous administration showed that only fraction 1 induced a granulomatous reaction and death in mice.
\end{abstract}

\section{INTRODUCTION}

Chromomycosis or verrucose dermatitis is a chronic mycotic infection of man, usually limited to the skin and subcutaneous tissue (Greer et al., 1979). Members of the family Dematiaceae (dark brown or black fungi) are the main causative agents. Proliferation of the fungus causes a localised suppurative and granulomatous reaction. At first the characteristic histopathological picture is one of multiple stellate abscesses. These develop into a single circumscribed lesion with a purulent centre surrounded by a fibrous wall. There are no systemic effects and the regional lymph nodes are not affected. Patients with immune deficiency or debilitating disease are at increased risk (Vollum, 1977; Ziefer and Connor, 1980).

Studies on many pathogenic fungi suggest that various cell constituents are related to pathogenicity. The most frequently mentioned have been lipids (Peck, 1947) and cell-wall polysaccharides (San-Blas, 1982). Silva and Ekizlerian (1985) reported one of the few attempts made to isolate a substance from Fonsecaea pedrosoi, F. compactum, Cladosporium carrioni and Phialophora verrucosum cells that might be responsible for the lesions in chromoblastomycosis. They found that a lipid fraction induced pulmonary granulomatous reactions in mice.

In this report we examine the possibility that the inflammatory responses in chromomycosis are attributed not only to lipid but also to fungal cell-wall constituents. 


\section{MATERIALS AND METHODS}

Fungal strains and cultures. F. pedrosoi strain M-364, F. compactum 174, C. carrioni 370 and $P$. verrucosum M-173 were obtained from Dr Arlete M. Cury, Faculty of Pharmaceutical Sciences, University of São Paulo, Brazil. These strains were isolated from patients with chromomycosis and maintained as stock cultures on Sabouraud's dextrose agar. Saccharomyces cerevisiae was obtained from a commercial source. All strains except $S$. cerevisiae were grown at $25^{\circ} \mathrm{C}$ for 14 days in liquid medium containing glucose $2 \%$, peptone $1 \%$ and yeast extract $0.1 \%$. After sterilisation of each culture by treatment with formaldehyde (final concentration $0.5 \%$ ) for $24 \mathrm{~h}$, the mycelia were harvested with sintered glass funnels, washed with distilled water, and lyophilised.

Cell-wall preparation (lipid-extracted). The lyophilised mycelia ( $2 \mathrm{~g}$ suspended in $5 \mathrm{ml}$ of distilled water) were subjected to ultrasonic vibration at $200 \mathrm{~W}$ for $5 \mathrm{~min}$. This was repeated five times. A high degree of disruption was produced, as seen by phase-contrast microscopy. The cellwall material was washed repeatedly by centrifugation until phase-contrast microscopy indicated freedom from undisrupted hyphae and cytoplasmic components. After freeze-drying, the cell-wall samples were submitted to lipid extraction with chloroform: methanol $(2: 1, \mathrm{v}: \mathrm{v})$ as described previously by Silva and Ekizlerian (1985).

Cell-wall fractions 1, 2 and 3. The lipid-free wall material was extracted with alkali as described by Kanetsuna et al. (1972). Briefly, the material was suspended in $1 \mathrm{~N} \mathrm{NaOH}(10 \mathrm{mg} /$ $\mathrm{ml}$ ) and gently stirred at room temperature for $1 \mathrm{~h}$. After centrifugation at $5000 \mathrm{~g}$ for $10 \mathrm{~min}$, the supernate was collected; the procedure was then repeated four times and all the supernates were combined. The alkali-insoluble precipitate was washed with water until it reached $p \mathrm{H} 7$, and then sequentially with ethanol, acetone and diethyl ether. The resulting white powder was called fraction 1. T ' $e$ supernate was neutralised by the addition of acetic acid, left to stand overnight at $4^{\circ} \mathrm{C}$, and then centrifuged. The precipitate and supernate were collected, dialysed separately against distilled water and lyophilised, forming respectively fraction 2 (alkali-soluble, acidprecipitable) and fraction 3 (alkali-soluble, acid non-precipitable).

Trypsin treatment of cell-wall preparation and fraction 1. The cell-wall preparation and fraction 1 were each resuspended in phosphate buffer $(0 \cdot 1 \mathrm{M})$ containing trypsin $(100 \mu \mathrm{g} / \mathrm{ml})$ and incubated in a shaking waterbath for $3 \mathrm{~h}$ at $37^{\circ} \mathrm{C}$. Each suspension was then centrifuged at $17000 \mathrm{~g}$ for $10 \mathrm{~min}$, its supernate discarded, and the pellet washed repeatedly with distilled water. The last procedure was repeated until the washings failed to absorb the light at $280 \mathrm{~nm}$, indicating removal of residual enzyme.

Acid hydrolysis of fraction 1 . Fraction 1 was hydrolysed with $6 \mathrm{~N} \mathrm{HCl}$ at $110^{\circ} \mathrm{C}$ for $16 \mathrm{~h}$. The remaining $\mathrm{HCl}$ was then removed by repeated evaporation in vacuo over silica gel and $\mathrm{NaOH}$ pellets. Residues were dissolved in a small amount of water and passed through a column $(1.0 \times 10.0 \mathrm{~cm})$ containing Amberlite IR $120\left(\mathrm{H}^{+}\right.$form $)$and Amberlite IR45 $\left(\mathrm{OH}^{-}\right.$form $)$with water as eluent. Desalted solutions were concentrated by lyophilisation.

Evaluation of pulmonary granulomatous reaction. The granulomatogenic properties of cellwall preparation (lipid-extracted) and fractions 1-3 were assessed histologically and by recording the lung index (see below) after giving mice (Balb/c, weighing 20-25g), intravenously, $200 \mu \mathrm{g}$ of each preparation in $0.1 \mathrm{ml}$ of saline. The intravenous injections were made into the retro-orbital venous plexus instead of the more commonly used caudal veins. For histological analysis, the animals were anaesthetised with ether and killed by exsanguination. The lungs were fixed with Bouin's fixative $(2 \mathrm{ml})$ injected into the exposed trachea. They were then cut through the hilus, dehydrated in graded ethyl alcohol and embedded in paraffin. Five sections cut sequentially were stained with haematoxylin and eosin. For recording the lung index, the animals were killed by cervical dislocation and weighed; their lungs were then removed, trimmed of extraneous tissue, rinsed in saline, blotted and weighed. The lung index was calculated by the method of Allen et al. (1977):

$$
\text { Lung index }=\frac{\text { (organ weight } / \text { body weight of test animal) }}{\text { (organ weight } / \text { body weight of control animal) }}
$$

Toxicity. The toxicity of cell-wall preparation (lipid-extracted) and fractions 1-3 was evaluated by giving mice, by intraperitoneal injection at 2-day intervals, five doses of $5 \mathrm{mg}$ in $\mathbf{0 . 2}$ $\mathrm{ml}$ of saline (cell wall) or $3 \mathrm{mg}$ in $0.2 \mathrm{ml}$ of saline (fractions) and recording weight loss and deaths. 


\section{RESULTS}

\section{Toxicity of the cell-wall preparation (lipid-extracted) before and after trypsinisation}

The toxicity of cell-wall preparations from $F$. pedrosoi, $F$. compactum, $C$. carrioni and $P$. verrucosum was tested. The weight losses of mice are shown in table I. All preparations caused a pronounced weight loss within 4 days of the first injection. The animals were reluctant to move and their fur appeared wet and rough; they had lost 13$19 \%$ of their initial body weight by day 12 of the experiment and the deaths occurred between days 21 and 28 (table II). At necropsy, peritonitis with an inflammatory exudate, numerous granulomas in the liver, and splenomegaly were observed. Control mice given a cell-wall preparaton from $S$. cerevisiae did not die and showed no toxic effects; they had gained $30 \%$ in body weight by day 28 . Trypsinisation of cell-wall preparations may have slightly increased their lethal effects for mice (table II) but the evidence was not statistically significant.

\section{Toxicity of cell-wall fractions $1-3$}

Fraction 1 prepared from each of the four chromomycosis fungal strains was toxic for mice; it caused progressive wasting and rapid loss of body weight (table I). Deaths occurred within 3-4 weeks of the beginning of the test. Mice given fractions 2 and 3 remained healthy, gained weight normally and showed no pathological changes when killed on day 60 of the test. Trypsinised fraction 1 had lethal properties, but after acid hydrolysis fraction 1 was non-toxic (table II). Fractions 1-3 prepared from $S$. cerevisiae were without toxic effect (table I).

\section{Evaluation of pulmonary granulomatous reaction}

The pulmonary inflammatory reaction induced by cell-wall preparation (lipidextracted) and fractions 1-3 was determined by calculating the lung indices and by histological examination 2, 4, 8, 16 and 32 days after the intravenous inoculation of $200-\mu \mathrm{g}$ doses. Fig 1 shows that, by the second day of the experiment, the lung index had increased in animals given the cell-wall preparation and fraction 1 but not in those given fraction 2 or 3 . Histological examination of the lungs of animals given cell-wall preparation or fraction 1 revealed a striking infiltration of polymorphonuclear and mononuclear cells on the second day. This infiltration increased, reaching a peak at about day 16. Histological examination also showed an intense focal inflammatory reaction consisting of mononuclear cells with morphological traits similar to those of macrophages and epithelioid cells (fig. 2). The chronic granulomatous lesions induced by two preparations were still evident by the 32 nd day.

\section{Discussion}

The pathogenesis of an infectious disease depends upon two main factors, namely, host resistance and the virulence of the infecting organism. We examined possible virulence factors in relation to the pathogenesis of chromomycosis.

The biochemical mechanisms whereby $F$. pedrosoi, $F$. compactum, $C$. carrioni and 


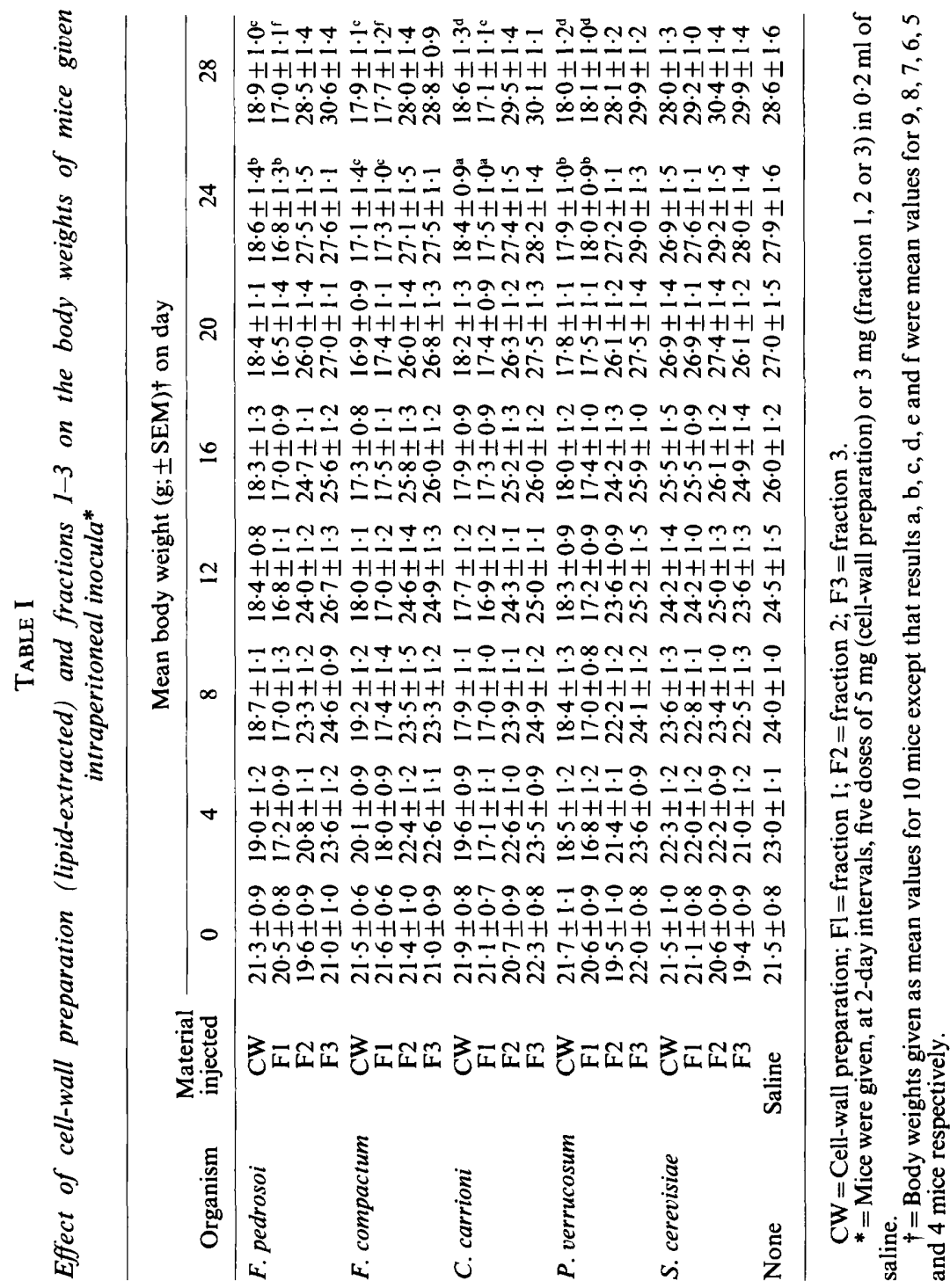




\section{TABLE II}

Lethal effect of cell-wall preparation (lipid-extracted) and cell-wall fractions 1-3 in mice given intraperitoneal inocula

\begin{tabular}{lccccc}
\hline & \multicolumn{5}{c}{ Deaths in groups of 10 mice* treated with } \\
\cline { 2 - 6 } \multicolumn{1}{c}{ Organism } & $\begin{array}{c}\text { cell-wall } \\
\text { preparation }\end{array}$ & $\begin{array}{c}\text { trypsinised } \\
\text { cell-wall } \\
\text { preparaton }\end{array}$ & fraction 1 & $\begin{array}{c}\text { trypsinised } \\
\text { fraction 1 }\end{array}$ & $\begin{array}{c}\text { fraction 1 } \\
\text { after acid } \\
\text { hydrolysis }\end{array}$ \\
\hline F. pedrosoi & 3 & 5 & 6 & 6 & 0 \\
F. compactum & 5 & 6 & 6 & 7 & 0 \\
C. carrioni & 4 & 6 & 5 & 5 & 0 \\
P. verrucosum & 4 & 5 & 4 & 5 & 0 \\
S. cerevisiae & 0 & 0 & 0 & 0 & 0 \\
\end{tabular}

* Experiment extended over a period of 28 days. Fractions 2 and 3 were without toxic effects in mice observed for 60 days.

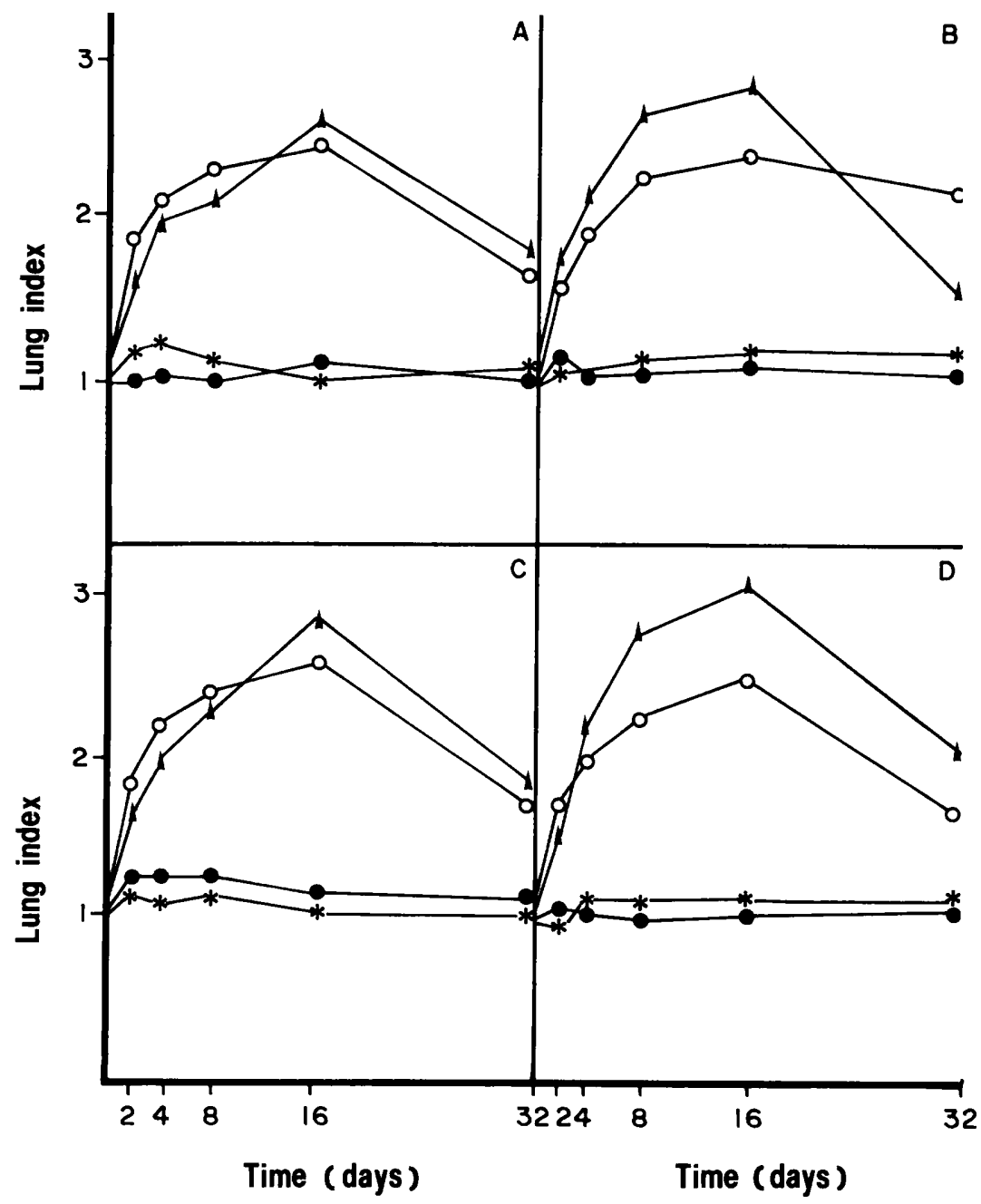

Fig. 1-Development of chronic inflammation in the lungs of mice given, intravenously, 200- $\mu \mathrm{g}$ doses of cell-wall preparation $(0)$, fraction $1(\Delta)$, fraction $2(*)$ or fraction $3(\bullet)$ from $F$. pedrosoi $(\mathrm{A}), F$. compactum (B), C. carrioni (C) or P. verrucosum (D). The lung indices are expressed as the mean values for five mice. 


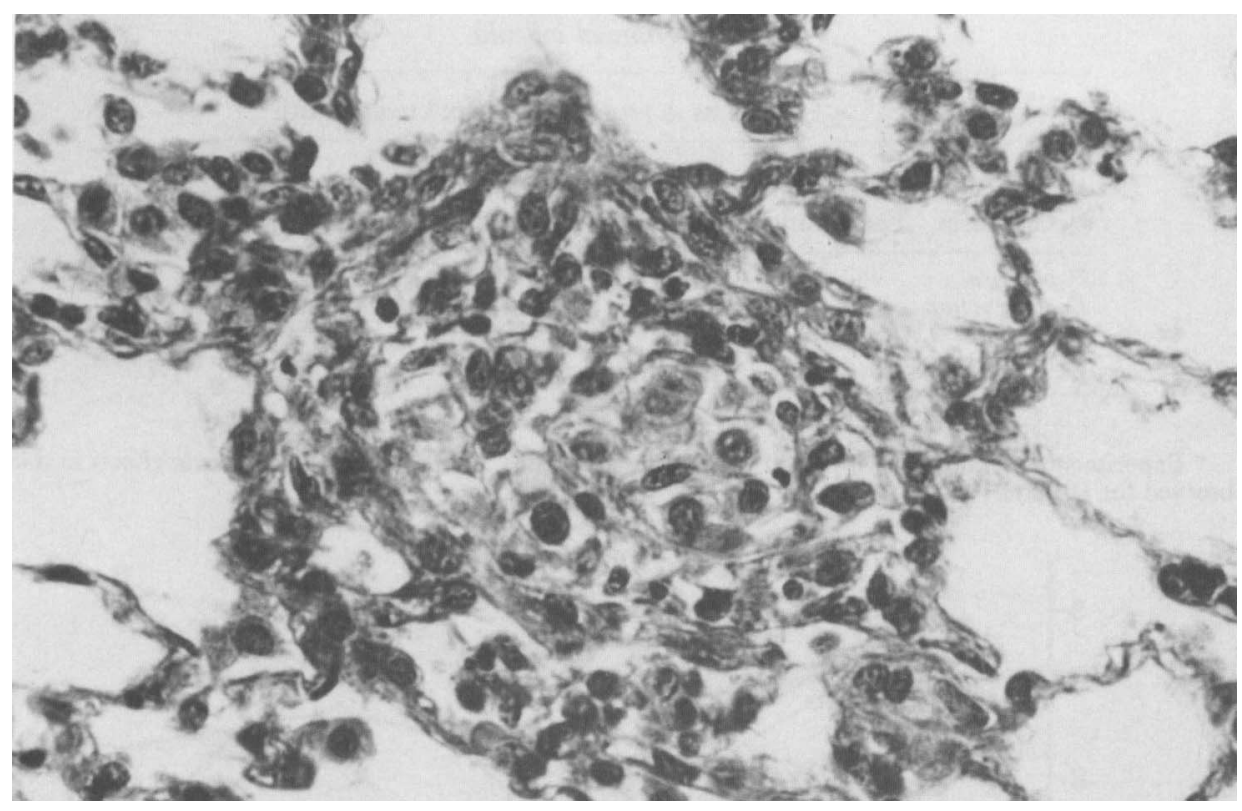

FIG. 2-Inflammatory reaction in the lung of a mouse 16 days after inoculation with fraction 1 from $F$. pedrosoi. The alveolar interstitium is densely infiltrated with mononuclear cells forming a loosely organised granuloma.

$P$. verrucosum produce disease in man are still unclear. The data presented in a previous paper (Silva and Ekizlerian, 1985) supported the idea that granuloma formation was induced by fungal lipid in very low concentrations. The present study leads us to conclude that the lesions of chromomycosis are attributable not only to lipid but also to fungal cell-wall constituents, previously shown by Szaniszlo et al. (1972) to differ significantly in sugar, amino-sugar and amino-acid content. Lipid-extracted cell walls and alkali-insoluble fraction 1 were toxic for mice, causing progressive wasting, rapid loss of body weight and, sometimes, death within 2-4 weeks.

Taylor (1964, cited by Cox et al., 1974) reported that killed yeast-phase cells of Blastomyces dermatitidis were lethal for mice and that treatment of the cells with trypsin significantly enhanced their toxicity. In evaluating the effect of trypsin on the toxicity of the cell walls of chromomycosis agents, we found that the trypsinisation of these preparations may have slightly increased their lethal effects for mice but the evidence was not statistically significant.

Intravenous inoculation of cell-wall preparation or fraction 1 in mice caused a striking increase in the lung-weight to body-weight ratio; this was due to a chronic interstitial and alveolar granulomatous response similar to that induced by $B$. dermatitidis (Harvey et al., 1978). Studies are now needed to characterise the cell-wall constituent responsible for the pathological reaction.

\section{REFERENCES}

Allen E M, Moore V L, Stevens J O 1977 Strain variation in BCG-induced chronic pulmonary inflammation in mice. 1. Basic model and possible genetic control by non- $\mathrm{H}-2$ genes. Journal of Immunology 119:343-347. 
Cox R A, Mills L R, Best G K, Denton J F 1974 Histologic reactions to cell walls of an avirulent and a virulent strain of Blastomyces dermatitidis. Journal of Infectious Diseases 129:179-186.

Greer K E, Gross G P, Cooper P H, Harding S A 1979 Cystic chromomycosis due to Wangiella dermatitidis. Archives of Dermatology 115:1433-1434.

Harvey R P, Schmid E S, Carrington C C, Stevens D A 1978 Mouse model of pulmonary blastomycosis: utility, simplicity, and quantitative parameters. American Review of Respiratory Disease 117: 695-703.

Kanetsuna F, Carbonell L M, Azuma I, Yamamura Y 1972 Biochemical studies on the thermal dimorphism of Paracoccidioides brasiliensis. Journal of Bacteriology 110:208-218.

Peck R L 1947 The lipids of fungi with special references to pathogenic fungi. In: Nickerson W J (ed) Biology of pathogenic fungi. Ronald Press, New York, pp 162-188.

San-Blas G 1982 The cell wall of fungal human pathogens; its possible role in host-parasite relationships. Mycopathologia 79:159-184.

Silva C L, Ekizlerian S M 1985 Granulomatous reaction induced by lipids extracted from Fonsecaea pedrosoi, Fonsecaea compactum, Cladosporium carrionii and Phialophora verrucosum. Journal of General Microbiology 131:187-194.

Szaniszlo P J, Cooper B H, Voges H S 1972 Chemical compositions of the hyphal walls of three chromomycosis agents. Sabouraudia 10:94-102.

Vollum D I 1977 Chromomycosis: a review. British Journal of Dermatology 96:454-458.

Ziefer A, Connor D H 1980 Phaeomycotic cyst. A clinicopathologic study of 25 patients. American Journal of Tropical Medicine and Hygiene 29:901-911. 